\title{
Rational a priori or Emotional a priori? Husserl and Scheler's Criticisms of Kant Regarding the Foundation of Ethics
}

\author{
Wei ZHANG \\ Department of Philosophy, Sun Yat-sen University \\ No. 135 Xingang Xi Road, Guangzhou 510275, China \\ renzhizhang@hotmail.com
}

\begin{abstract}
Based on the dispute between Protagoras and Socrates on the origin of ethics, one can ask the question of whether the principle of ethics is reason or feeling/emotion, or whether ethics is grounded on reason or feeling/emotion. The development of Kant's thoughts on ethics shows the tension between reason and feeling/emotion. In Kant's final critical ethics, he held to a principle of "rational a priori." On the one hand, this is presented as the rational a priori principle being the binding principle of judgment. On the other hand, it is presented as the doctrine of "rational fact" as the ultimate argument of his ethics. Husserl believed that Kant's doctrine of a rational a priori totally disregarded the a priori essential laws of feeling. Like Husserl, Scheler criticized Kant's doctrine of a rational a priori, and therefore developed his own theory of an "emotional a priori". Both of them focused their critiques on the grounding level of ethics. Scheler, however, did not follow Husserl all the way, but criticized him and reflected on his thoughts. At last, he revealed the primary status of a phenomenological material ethics of value.
\end{abstract}

Keywords: rational a priori, emotional a priori, the principle of judgment of morality, moral insights, the foundation of ethics

Based on the dispute between Protagoras and Socrates on the origin of ethics, one can ask the question, as Brentano did, of whether the principle of ethics is reason or feeling/emotion, or whether ethics is grounded on reason or feeling/emotion. In Kant's final critical ethics, he held to a principle of "rational a priori." But Husserl believed that Kant's doctrine of a rational a priori totally disregarded the a priori essential laws of feeling. Like Husserl, Scheler criticized Kant's doctrine of a rational a priori, and therefore developed his own theory of an "emotional a priori." Scheler, however, did not follow Husserl all the way. On the contrary, just before the First World War he revealed the primary status of a phenomenological material ethics of value by means of a critique of Husserl's ethics. 
In the first section, we will discuss the principle of "rational a priori" in Kant's ethics. Then, Husserl and Scheler's criticisms of Kant's principle will be discussed separately in the second and third section. At last, in the final section, we will focus on the basic positions of Husserl and Scheler on the foundation of phenomenological ethics.

\section{THE PRINCIPLE OF RATIONAL A PRIORI IN KANT'S ETHICS}

From 1770 onwards, Kant held that ethics is grounded on pure reason. He distinguished "the binding principle of judgment" (das principium der Diiudication der Verbindlichkeit/das Prinzip der Beurteilung der Verbindlichkeit) from "the binding principle of execution" (das principium der Execution oder Leistung der Verbindlichkeit/das Prinzip der Ausübung der Verbindlichkeit) in order to clarify the position and function of feeling in ethics. Kant regarded the guideline (Richtschnur) as the principle of judgment, and the incentive (Triebfeder) as the binding execution (Kant, 2004: 55f). It means that the foundation of ethics involves only "the principle of judgment"; that is to say, ethics is grounded only on pure reason, but moral feeling can be attributed only to "the principle of execution." Thus, Kant's mature critical ethics can be called "the ethics of pure Reason." In his Groundwork of the Metaphysics of Morals, Kant explicitly regarded the autonomy of the will as the highest principle of morality (Kant, 2007: 440). Kant wrote, "The will is thought as a capacity to determine itself to acting in conformity with the representation of certain laws" (Kant, 2007: 427). And, the will is always identified with practical reason by Kant. ${ }^{1}$ So it is clear that ethics, for Kant at that time, is grounded on reason or practical reason.

Further, Kant distinguished explicitly a formal principle from a material principle. He said, "Practical principles are formal if they abstract from all subjective ends, whereas they are material if they have put these, and consequently certain incentives, as their basis" (Kant, 2007: 427). In his later Critique of Practical Reason, Kant stressed:

if a rational being is to think of his maxims as practical universal laws, he can think of them only as principles that contain the determining ground of the will not by their matter but only by their form ... Now, all that remains of a law if one separates from it everything material, that is, every object of the will (as its determining ground), is the mere form of giving universal law. (Kant, 2003: 27) 
Clearly, in his mature critical ethics of pure reason, Kant regarded formal principles, the principle of autonomy or the principle of a priori reason, which differs from the material principle, the principle of heteronomy and the principle of a posteriori feeling, as the principles of judgment of morality or universal legislation.

Kant even called heteronomy of the will "the source of all spurious principles of morality". There are two kinds of heteronomy according to Kant: the empirical (empirisch) and the rational (rational) principles of heteronomy. As to these two principles, Kant is confronted with double task. On the one hand, he must overcome the "emptiness" of the rational basis of morality (such as the principle of perfection) and, on the other hand, the function and role of feeling in ethics must be specified.

It is by his stress upon the law of execution of morality that Kant achieved this double task. First of all, the so-called law of execution of morality is related to "the respect for the practical principle" as "the incentive of pure practical reason." In Kant's view, respect (Achtung) can only be regarded as the result of law rather than as the cause of it. Such a special kind of moral feeling, therefore, is incapable of becoming the principle of judgment in morality, no matter how important it is. Thus Kant said that any genuine supreme basic principle of morality has to rest on pure reason alone, independently of all experience (Kant, 2007: 409).

The attempt to overcome radical empiricism and scepticism in ethics required Kant to answer the question, "How is such a synthetic practical proposition possible a prior? And why it is necessary?" (Kant, 2007: 444). This meant that Kant must give his ethics the ultimate foundation (Begründung).

In Chapter 3 of Groundwork of the Metaphysics of Morals (GMS III for short), Kant tried to transcendentally deduce the concept of laws of morality from the concept of "free," usually called the transcendental deduction of moral laws. There are, however, some insuperable difficulties in such an attempt of transcendental deduction. ${ }^{2}$ For this reason, Kant had no choice but to attempt to find another way in his Second Critique to give his ethics the ultimate foundation. This new attempt is contained in the doctrine of "facts of reason" (Faktum der Vernunft).

Kant said:

Consciousness of this fundamental law [das Bewusstsein dieses Grundgesetres] may be called a fact of reason because one cannot reason it out from data antecedent to 
reason, for example, from consciousness of freedom (since this is not antecedently given to us) and because it instead forces itself upon us of itself as a synthetic a priori proposition that is not based on any intuition, either pure or empirical. (Kant, 2003: 31, author emphasis)

In our view, it is the "consciousness" of the fundamental law of pure practical reason but not the law of morality that is called "facts of reason" by Kant. Or, more precisely, "in order to avoid misinterpretation in regarding this law as given, it must be noted carefully that it is not an empirical fact but the sole fact of pure reason" (Kant, 2003: 31). ${ }^{3}$ Due to the two words "consciousness" and "given" (gegeben) which are emphasized above, it seems that there is every reason for one to understand Kant's doctrine of "fact of reason" as phenomenological but not as ontological.

In Kant's view, such a "consciousness" of the law of morality is neither empirical intuition nor pure intuition. But then we must ask what such a non-empirical, immediate consciousness means at all, or how the law of morality is given. Fichte also called this issue into question and postulated an "intellectual intuition" (intellektuelle $A n$ schaunng $)^{4}$ to resolve it. Nevertheless, Kant clearly refused to recognize that such a capacity of "intellectual intuition" belongs to human reason, whether in theoretical philosophy or in practical philosophy. ${ }^{5}$ Therefore, what such a non-empirical, immediate consciousness implies is still in question. In this sense, one has reason to say that Kant's doctrine of "fact of reason" is groundless (grundlos) (Waldenfels, 2006: 21).

However, the "fact of reason" that was identified as the ultimate foundation for Kant's ethics fails to convince. It is therefore important that he turned from the strategy of the transcendental deduction in GMS III to the strategy of developing this "fact of reason." From such a turn, one can find a new possibility for establishing the ultimate foundation for ethics; that is, developing the arguments for ethics on the basis of moral insights or phenomenological intuition.

\section{HUSSERL'S CRITIQUES OF KANT'S RATIONAL A PRIORI}

In ethics, Husserl's criticism of Kant was focused on his principle of a rational a priori, according to which, as to the matter of the foundation of ethics, Kant radically excluded the moments of sense and feeling, in another words, the empirical moments. In Husserl's view, Kant totally overlooked the a priori essential law in the field of feeling or 
disposition (Gemüt) and therefore missed the real foundation of ethics. In this sense, we can say that, from the beginning, Husserl's criticism of Kant was focused on Kant's principle of judgment of morality, that is, Kant's foundation of ethics. In the scope of our theme, I think there are three main aspects of Husserl's criticism of Kant's ethics. ${ }^{6}$

First, reason is thoroughly distinguished from sensitivity or feeling by Kant. He regarded sensitivity or feeling as something that has nothing to do with the foundation of ethics or the principle of judgment of morality. Obviously, with regard to the matter of the foundation of ethics, Kant totally excluded the distinction he suggested before, which plays an important role in the ethics, that is, the distinction between the feelings of lower lever and higher level (Höffe, 2007: 202). But, following Brentano, Husserl again stressed such a distinction (Brentano, 1955: 21ff). ${ }^{7}$ For Husserl, the fundamental mistake of Kant lies in the fact that Kant sensualized (sensualisieren) feeling (Hua XXXVII, 2004: 233). The reason for this is that Kant still shared the preconceptions of his opponents, who were sensualists or naturalists, that is, "feeling is the mere natural fact of the psycho-physical organism of human being" (Hua XXXVII, 2004: 227). For Husserl, a priori firstly means the objective essence. Thus, Husserl attempted to look for and find such an objective a priori, or "a priori essential law," in all the spheres of consciousness including reason and feeling.

Second, in Husserl's view, "the total opposition between sensitivity and reason" in Kant "is fundamentally wrong" (Hua XXXVII, 2004: 220) ${ }^{8}$ and therefore one cannot radically rule out the phenomenon of feeling in its relevance to the foundation of ethics just to achieve the a priori and absoluteness of ethics. For Husserl, "a universal ethics obviously must be founded on the theory of value" (Hua XXXVII, 2004: 24). Husserl further emphasized that such a theory of value is related to feeling at first, "the one who correctly acts do the right thing, and do the good thing. In this connection, the good is the practical good. It must be regarded both as good and as value" (Hua XXVIII, 1988: 414).

And, such "regarding as" takes place in "rational' feeling" (vernünftiges Füblen) (Hua XXVIII, 1988: 414). In other words, in Husserl's view, a universal ethics should be founded on the theory of value, and the theory of value should ultimately be founded on such a "rational feeling". Just through this feeling, the good thing that was done or the practical good can be regarded both as value or good. And only if such a feeling of "regarding as good" goes ahead can one act well. This seemingly contradictory expression of "rational feeling" was re- 
placed by Husserl later with the more precise term "intentional feeling." It is the phenomenological analysis of the "rational feeling" or "feeling of intentionality" as a "valuelized act" (wertender Akt) that forms the starting point of Husserl's phenomenological ethics. For Husserl, the practical law is not a formal but a material "truth of reason." A genuine morality cannot be prescribed only by "the form of rational a priori" but requires a "material determination of the will" (Hua XXVIII, 1988: 402f; Hua XXXVII, 2004: 232f).9 Therefore, Kant's requirement of a categorical imperative is totally "absurd" (widersinnig) for Husserl (Hua XXXVII, 2004: 233, 235).

Thirdly, according to Kant, the moral categorical imperative is given in non-empirical, immediate consciousness. He called this the "fact of reason". Husserl called the categorical imperative "the most central problem of ethics" too (Hua XXVIII, 1988: 137), but did not accept Kant's definition of the categorical imperative. He followed Brentano who suggested a "formal categorical imperative" (that is, "to do the best that you can of what is achievable!" (Tue das Beste unter dem Erreichbaren.)) (Brentano, 1955: 15f; 1978: 134ff, 222ff). For Husserl, there are two radical absurdities in Kant's theory of the categorical imperative. The first one is that Kant's categorical imperative is not immediately evident but it requires a "choice" ( $W a b l)$, which means "to choose to do the best as you can", or "never to choose the less good when you can do a greater good" (Spahn, 1996: 30f, 140; Hua XXVIII: 132 ff; Melle, 1991: 120f). The second absurdity, in Husserl's view, is that Kant's categorical imperative is "empty" (leer). The faculty of universalization that is "merely formal" makes something completely "empty": "The empty possibility of universalizing demonstrates neither the justifiability of logic and aesthetics, nor the justifiability of ethics" (Hua XXXVII, 2004: 417f). For this reason, Husserl criticized the "formalism" in Kant's ethics (Hua XXVIII, 1988: 414-8).

We can say, therefore, that Husserl criticized Kant's theory of the categorical imperative on two completely different levels. His criticism that Kant's categorical imperative cannot serve as the grounds of prescription of the will refers to the relationship between formal theory of value and formal "practics" in Husserl. It means that the grounds of the determination of the will should be ultimately found in the formal theory of value. His criticism that Kant's categorical imperative is empty is one made inside the formal practics. ${ }^{10}$

Fundamentally, in Husserl's view, Kant completely ignored the a priori essential law in the fields of feeling and disposition, and did not grasp the concept of intentional feeling. Thus, Kant's ethics, or, more 
precisely, the foundation Kant gives to ethics, again falls into absurdity (Hua XXVIII, 1988: 139).

\section{SCHELER'S CRITICISM OF KANT'S RATIONAL A PRIORI AND THE PRINCIPLE OF AN EMOTIONAL A PRIORI}

Just as in Husserl, there is a gap between Scheler's and Kant's approaches to ethics. According to Scheler, Kant's rational reason is an "unfounded restriction and limitation of the a priori," which "also has its roots in his identification of the a priori with the "formal"" (Scheler, 1980: 83/64). Scheler said, "Kant's identification of the "non-formal" (material) (in both the theory of cognition and ethics) with "sensible [sinnlichen] content" and the "a priori" with what is "thought" or what has been an addition to such "sensible content" by way of "reason"" is his fundamental error (Scheler, 1980: 73/54). It shows that Kant still shares the mistaken premise of sensualism, as Husserl had already suggested critically. In Scheler's view, it is through the concepts of "acceptance-spontaneity" that Kant developed a "mythology of productive rational activity." And the fundamental error of Kant's theory of the a priori comes from just such a mythology. Due to the mythology, "the 'form' to which the a priori is falsely restricted, is, or is supposed to be, the result of a forming activity, of a 'forming' and a 'synthesizing" (Scheler, 1980: 84/66). In fact, the mythology of Kant "is a purely constructivist explanation" and is not based on intuitive or phenomenological experience. Besides, it is in this mythology that Kant disclosed his own basic attitude and basic position toward the world, that is, "a hatred of the world [Welthass]" (Scheler, 1980: 86/67).

Such a hatred of the world led Kant to classify all the important feelings in ethics (even including love and hate"11) as "disordered chaos" or field of mere sensitivity and therefore to exclude them on the foundational level of ethics. Just as Husserl, Scheler here followed Brentano's basic claim. He believed that there is a basic distinction between lower and higher feelings. Kant, however, eliminated and fused this distinction in the fundamental dichotomy of reason and sensitivity. Even the sole exception of "the feeling of respect" in Kant has nothing to do with the principle of judgment of morality (Scheler, 1980: 247f, 240ff, 391ff).

Scheler completely agreed with Kant's critique of all the Epicureanism/hedonism in ethics. They both believed that there can never be a field of a priori in Epicureanism, and that Epicureanism was bound to 
finally lead toward the relativism and scepticism in ethics. But Scheler did not totally reject the starting point of Epicureanism, as Kant did. Scheler demonstrated ethics by emotions, and developed an "a priori emotion" for founding his a priori and at the same time material ethics by revealing the a priori of the field of emotions. ${ }^{12}$

Briefly, in Scheler, all the feelings are not "a disordered chaos" and there are essential differences in quality and depth in the field of feeling. ${ }^{13}$ Thus, in contrast with Kant's "hatred of the world," Scheler's basic position and attitude to the world is the "lived affair with the world" (lebendigen Verkehr mit der Welt) (Scheler, 1980: 87/68) in feeling and emotion. Like Husserl, Scheler found the a priori essential law in the field of feeling. Therefore, the "lived affair with the world" of Scheler could well be feeling or emotional, and at the same time absolute or a priori.

Scheler said clearly, "The emotive elements of spirit, such as feeling, preferring, loving, hating and willing, also possess original a priori contents which are not borrowed from 'thinking,' and which ethics must show to be independent of logic" (Scheler, 1980: 82/63).

The "original a priori" is completely independent of inductive experiences, and independent of the experience of epistemology in general. On the contrary, "as with thought, there is the intuiting of essences of acts and their correlates, their foundations, and their interconnections. In both cases there is 'evidence' and maximum exactness of phenomenological findings [strengste Exaktheit der phaenomenologischen Feststellung]" (Scheler, 1980: 84/65).

Or, as Paul Good pointed out correctly, such an evidently essential a priori of emotion/feeling can be called "grammar of feeling" (Grammatik der Gefüble). (Good, 2000: 21ff, 25ff). ${ }^{14}$

Therefore, Scheler claimed that there is a priori "order of heart" (ordre du coeur) or "logic of heart" (logique du coeur), as Blaise Pascal aptly called it (Scheler, 1980: 260/254). The "order" or "logic" here is completely different from the "reason" in general logic, but means "the non-logical a priori aspect" at first. Then, says Scheler,

axioms of values are wholly independent of logical axioms and are not mere "applications" of the latter to values. Logic and a pure doctrine of values [reine Wertlehre] stand side by side ... The phenomenology of values and the phenomenology of emotive life are completely independent of logic, having an autonomous area of objects and research. (Scheler, 1980: 83/64).

His phenomenological material ethics of value is founded on just such a pure theory of value and the phenomenology of emotional life. 
The establishment of an a priori-material ethics primarily requires us to abandon the dualistic supposition that the opposition of "reason" and "sensitivity" is enough to define the spirit of human beings, or that the human spirit can be divided into either one or the other. Scheler's intention is very clear. He is unable to accept the ethics of pure reason that Kant criticized, not to mention unable to accept the other side of the dualistic opposition that is denied by Kant; that is to say, he will not simply turn back to ethics before Kant or before Kant's critical period. For that reason, although Scheler completely denied Kant's "Copernican revolution," we are unable to say he instigated a "Ptolemaic counterrevolution" at all. Scheler's fundamental position is to radically cancel such an "either-or" dualistic opposition itself. Or, we can say, it is just the significance of a phenomenological revolutionary, whether on the level of theoretical philosophy, or on the level of practical philosophy!

Finally, Scheler developed an "emotional a priorism" and also an "ethics of a priori-emotion," of which the latter is relative to both general empirical ethics of emotion (such as Epicureanism) and an absolute, a priori ethics of reason (such as Kant's pure critical ethics). In Scheler's view, however, Kant did not pay attention to the "circle of facts" (Tatsachenkereis), which provides the basis for such an "ethics of a priori-emotion". And the "rational facts" to which Kant resorted to demonstrate his ethics of a priori reason is still "ungrounded." Scheler (1980: 66/47) asked, "What is the difference between a 'fact of pure reason' and a merely psychological fact?" For Scheler, because of the absence of a "phenomenological experience" or intuition of essence, Kant could not answer this question at all. In contrast with Kant, Scheler took the concept of "phenomenological or pure facts" as the ultimate basis of his phenomenological ethics. The "phenomenological or pure facts" in Scheler imply the self-given "material a priori" in phenomenological experience or intuition of essence, but such a "material a priori" contains three kinds of a priori which are different but relevant to each other: a priori acts, the a priori fact-contents of acts, and the a priori essential interconnections of acts to their factcontents. These three kinds of a priori are all material a priori, for they can all be self-given as "material" in phenomenological experience. On the level of ethics, they are shown as emotional a priori, value a priori (which is grasped in emotion) and the relevant a priori of emotion-value. 


\section{REASON OR EMOTION: HUSSERL AND SCHELER'S FOUN- DATIONS OF PHENOMENOLOGICAL ETHICS}

In Husserl, evaluating acts, intentional feeling and so-called "rational feeling" are basically subjected to reason in general. In this sense, therefore, we cannot even say that, in contrast with Kant's rational ethics, Husserl developed an ethics of emotion or a moral philosophy of feeling. Rather, Husserl still held on to a rational ethics. But such a reason comes to be a "universal reason," the sense of which is expanded by Husserl. For him, reason is "a title for an all-embracing essentially necessary structural form belonging to all transcendental subjectivity. Reason refers to possibilities of verification; and verification refers ultimately to making evident and having as evident" (Hua I, 1950: 92). According to this, the final requirement of phenomenology in general is to develop a "complete rational phenomenology" and such a complete rational phenomenology would eventually be in accordance with or consistent with "phenomenology in general" (Hua III/1, 1976: 323). On the level of ethics, Husserl finally developed a universal, rational self-conditioned idea (Hua XXXVII, 2004: 243ff). ${ }^{15}$

Different from Husserl, Scheler decisively developed an emotional a priorism and ethics. For Scheler,

there is also a pure intuiting and feeling, a pure loving and hating, a pure striving and willing, which are as independent of the psychophysical organization of man as pure thought, and which at the same time possess their own original laws that cannot be reduced to laws of empirical psychic life. (Scheler, 1980: 259f./254)

Such a pure feeling, a pure preferring, a pure loving and hating is signified as "value-intuition," "value-cognition" or "moral insight" by Scheler. And he believed that "all ethics must go back to the facts lying in moral cognition and their a priori interconnections" (Scheler, 1980: 88). ${ }^{16}$ At the same time, Scheler emphasized, "moral cognition and moral insight themselves are not ethics." In this connection, in fact, Scheler regarded the theory of value and the theory of moral cognition as the introduction of an ethics upon which the phenomenological ethics will finally be founded. ${ }^{17}$ Then it is clear that, different from Kant, Scheler founded his phenomenological material ethics of value on a priori emotionality, by which he explicitly and clearly answers the question he proposed (1980: 260/254): "Can an ethics be both absolute and emotional?" 
It can be said that both the rational ethics expanded by Husserl and the emotional ethics expanded by Scheler are a priori, absolute ethics. Both of them are different from Kant's ethics, and take in the elements of a priori emotion. But these two kinds of expansion lead the acts of human spirit in different directions (one toward reason, another toward emotion/feeling). And the fates of their phenomenological ethics are also different.

As Husserl announced, "no one has any way to deny the universal control of logical reason," and evaluating and practical reason is dumb and somehow deaf, "so the torch of logical reason must be held high, so as to illuminate what is obscured in the forms and norms of the field of disposition and willing" (Hua XXVII, 1988: 57, 59, 68f). After all, inside the expanded concept of reason, Husserl finally insists on the domination of reason to sensitivity, which was repeatedly insisted on by Kant. Their distinction only lies in the fact that Kant's reason and sensitivity both put on the coat of reason (expanded by Husserl), and achieve the a priori. The premise of Kant's dualism, however, reappears with another face. More essentially, the traditional prejudices about the status of reason and sensitivity suppress the original position of phenomenological ethics once again. Ethics is always quasitheoretical science, although it is universal and a priori. ${ }^{18}$

In Scheler, however, the expansion of the concepts of "emotion" or "feeling" offers an entirely different possibility. Both the act of feeling and the act of representation have their own essential forms of intentionality according to Scheler. They both are independent acts of spirit and therefore cannot be reduced to each other. Based on this, if the act of feeling itself has its own special relation with the object, and is itself an independent act, then the dependence of the act of feeling on the act of representation or, more precisely, the dependence of the act of feeling on the material of the act of representation, or the founding relation of the act of feeling to the act of representation, is untenable. ${ }^{19}$

What's more, Scheler entirely turns over Husserl's "material founding relation" in order to gain the "original" position of the act of value-feeling and its correlate (value). In Scheler's view, "valueception [Wertnebmen] ... precedes all representational acts according to an essential law of origins. Its evidence is largely independent of the evidence of representations [vor-stellen]" (Scheler, 1980: 209f./201), "any intellectual comprehension of what something is presupposes an emotive value experience of the object ... Value-ception [Wertnehmung] always precedes perception [Wahrnehmung]" (Scheler, 1980b: 109f.). ${ }^{20}$ 
The achievement of Scheler's turning-over may be seen as the gaining of the primacy of phenomenological material ethics of value relative to epistemology. And such an a priori-emotional ethics is eventually based on the immediate, original, lived affair with the world, in other words, a love of the world. ${ }^{21}$

\section{References}

Allison, E. Henry. Kant's theory of freedom. Cambridge: Cambridge University Press, 1990.

Beck, Lewis White. A Commentary on Kant's Critique of Practical Reason. Chicago: University of Chicago Press, 1960.

Beck, Lewis White. "Das Faktum der Vernunft. Zur Rechtfertigungsproblematik in der Ethik.”. Kant-Studien. 52 (1960/1961): S 271-81.

Brentano, Franz. Vom Ursprung sittlicher Erkenntnis. Eds. Oskar Kraus. Hamburg: Felix Meiner, 1955.

Brentano, Franz. Grundlegung und Aufbau der Ethik. Ed. Franziska MayerHillebrand, Hamburg: Felix Meiner, 1978.

Cobet, Thomas. Husserl, Kant und die praktische Philosopbie. Analysen zu Moralität und Freiheit. Würzburg: Königshausen \& Neumann, 2003.

Eisler, Rudolf. 1930. Kant-Lexikon. Nachschlagwerk zu Kants sämtlichen Schriften, Briefen und bandschriftlichen Nachlass. Hildesheim/Zürich/New York: Unveränderter Neudruck, 1984.

Fichte, Johann Gottlieb. "Zweite Einleitung in die Wissenschaftslehre." Johann G. Fichtes sämmtliche Werk, Bd. I. Ed. von J. H. Fichte. Berlin: Verlag von Veit und Comp., 1845.

Good, Paul."Vorwort: Max Scheler lesen heisst, den Sinn für Werte wecken.” Grammatik der Gefüble. Das Emotionale als Grundlage der Ethik. By Max Scheler. München: Dtv Verlag, 2000.

Henckmann, Wolfhart. Max Scheler. München: C. H. Beck Verlag, 1998.

Henrich, Dieter. "Die Deduktion des Sittengesetzes. Über die Gründe der Dunkelheit des letzten Abschnittes von Kant Grundlegung zur Metaphysik der Sitten." Denken im Schatten des Nibilismus. Festschrift für Wilhelm Weischedel zum 70. Geburtstag. Ed. A. von Schwan. Darmstadt: Wissenschaftliche Buchgesellschaft, 1975. S. 55-112.

Höffe, Otfried. Immanuel Kant. München: C. H. Beck Verlag, 2007.

Husserl, Edmund. Husserliana - Edmund Husserl. Gesammelte Werke. Dordrecht/Boston/London: Den Haag, 1950ff. Die Schriften von Husserl werden nach der Husserliana-Ausgabe zitiert als "Hua Band-Nr., Seite". Hua I: Cartesianische Meditationen und Pariser Vorträge. Ed. von Stephan Strasser, 1950; Hua III/1: Ideen zu einer reinen Phänomenologie und phänomenologischen Philosophie. Erstes Buch: Allgemeine Einführung in die reine Phänomenologie. In zwei Bänder. 1. Halbband: Text der 1.-3. Auflage. Ed.. von Karl Schuhmann, 1976; Hua XXVIII: Vorlesungen über Ethik und Wertlebre (1908-1914). Ed. von Ullrich Melle, 1988; Hua XXXVII: Einleitung in die Ethik. Vorlesungen Sommersemester 1920 und 1924. Ed. von Henning Peucker, 2004.

Kant, Immanuel. Practical philosophy. Trans. Mary. J. Gregor. Ed. Mary. J. Gregor. Cambridge: Cambridge University Press, 1996. 
Kant, Immanuel. Kritik der praktischen Vernunft. Eds. von Horst D. Brandt and Heiner F. Klemme. Hamburg: Felix Meiner, 2003.

Kant, Immanuel. Kritik der reinen Vernunft. Theoretische Philosophie, Bd. 1. Ed. von Georg Mohr. Frankfurt am Main: Suhrkamp, 2004.

Kant, Immanuel. Vorlesung zur Moralphilosophie. Ed. von Werner Stark. Berlin: Walter de Gruyter GmbH \& Co. KG, 2004a.

Kant, Immanuel. Grundlegung zur Metaphysik der Sitten. In Kants Gesammelte Schriften Akademieausgabe, Bd. IV. Frankfurt am Main: Suhrkamp, 2007.

Melle, Ullrich. "Zu Brentanos und Husserls Ethikansatz. Die Analogie zwischen den Vernunftarten." Brentano-Studien 1 (1988): 115-35.

Melle, Ullrich. “The Development of Husserl's Ethics." Études phénoménologiques 13-14 (1991): 109-20.

Peucker, Henning. "Husserl's Critique of Kant's Ethics." Journal of the History of Philosophy. 45.2 (2007): 309-19.

Scheler, Max. Max Scheler Gesammelte Werke. II (1980): Der Formalismus in der Ethik und die materiale Wertethik; VII (1973): Wesen und Formen der Sympathie/Die deutsche Philosophie der Gegenwart, VIII (1980b): Die Wissensformen und die Gesellschaft. Bern/München: Francke-Verlag; X (1986): Schriften aus dem Nachlaß, Bd. 1: Zur Ethik und Erkenntnislehre. Eds. von Maria Scheler and Manfred S. Frings. Bonn: Bouvier-Verlag.

Scheler, Max. Formalism in Ethics and Non-formal Ethics of Values. Evanston: Northwestern University Press, 1980a.

Scheler, Max. Problems of a Sociology of Knowledge. London: Routledge \& Kegan Paul, 1980.

Schönecker, Dieter. Kant: Grundlegung III. Die Deduktion des kategorischen Imperativs. Freiburg/München: Karl Alber Verlag, 1999.

Sepp, Hans Rainer. Praxis und Theoria. Husserls transzendentalphilosophische Rekonstruktion des Lebens. Freiburg/München: Karl Alber Verlag, 1997.

Spahn, Christine. Phänomenologische Handlungstheorie. Edmund Husserls Untersuchungen zur Ethik. Würzburg: Königshausen \& Neumann, 1996.

Stüttgen Albert. Der Gegenstandscharakter der Werte bei Scheler im Hinblick auf Husserl. Bonn: Universitaet Bonn, Diss. 1957.

Waldenfels, Bernhard. Schattenrisse der Moral. Frankfurt am Main: Suhrkamp Verlag, 2006.

Willaschek, Marcus. Praktische Vernunft: Handlungstheorie und Moralbegründung bei Kant. Stuttgart: Metzler Verlag, 1992.

Zhang, Wei. "The foundation of phenomenological ethics: Intentional feelings." Frontiers of Philosophy in China. 4.1. (2009): 130-42.

\section{Notes}

${ }^{1}$ For example, Kant, 2007: 412, 441. It should be especially mentioned here that Kant used the concept of "reason" (Vernunft) in two senses: 1) in the broader sense, reason is equal to high-level cognitive capacity as a whole, which includes "understanding" (Verstand) and reason in the narrow sense; and 2) in the narrow sense, reason refers to the highest level of cognitive capacity. Also see, Rudolf Eisler, Kant-lexikon. Nachschlagwerk zu Kants saemtlichen Schriften, Briefen und 
bandschriftlichen Nachlass, Berlin, 1930, unchanged reprinted version: Hildesheim/Zuerich/New York, 1984: 572ff. In this paper, the concept of reason is used in its broader sense, such as "rational a priori," "rational moral," etc. In the first place, it refers to a cognitive capacity of "a high-level," relative to "sensibility" or "feeling."

${ }^{2}$ Limited to the theme and length of this text, we are unable to exhaust the transcendental deduction of moral laws developed by Kant in GMS III and the difficulties existing in it. In the field of Kantian study, such a matter is the focus and central issue of study. There is an abundance of literature on it. In my view, the more important studies on it are the following: Dieter Henrich, "Die Deduktion des Sittengesetzes. Über die Gründe der Dunkelheit des letzten Abschnittes von Kant Grundlegung zur Metaphysik der Sitten." In Denken im Schatten des Nibilismus. Festschrift für Wilhelm Weischedel zum 70. Geburtstag. Ed. von Alexander Schwan. Darmstadt: Wissenschaftliche Buchgesellschaft, 1975. 55-112; Henry E. Allison, Kant's theory of freedom. Cambridge: Cambridge University Press, 1990, especially 214-229; Dieter Schönecker, Kant: Grundlegung III. Die Deduktion des kategorischen Imperativs. Freiburg/München: Alber, 1999.

3 As far as I know, there are three different opinions contained in the various interpretations of Kant's "fact of reason" in the field of Kantian study: 1) "Fact" means the law of morality itself (such as in Lewis White Beck and the like); 2) "fact" means the consciousness of the law of morality (such as, in Otfried Höffe and Henry E. Allison, and so on); and 3) Kant's "fact" (Faktum) comes from the Latin word factum whose original meaning is a means of action (Tat) (for example, in Marcus Willaschek, such an interpretation radically overturns the tradition and is, in fact, developed on the basis of Fichte's thoughts). Here, we accept the second opinion. Cf. Lewis White Beck, A Commentary on Kant's Critique of Practical Reason. Chicago: University of Chicago Press, 1960; von Karl-Heinz Ilting, Kants “Kritik der praktischen Vernunft'. Ein Kommentar. München: Wilhelm Fink Verlag, 1995. 158-168; L. W. Beck, "Das Faktum der Vernunft. Zur Rechtfertigungsproblematik in der Ethik." Kant-Studien. 52 (1960/1961): 271282; Otfried Höffe, Immanuel Kant. München: Beck, 2007. 207-212; Henry E. Allison, Kant's theory of freedom. Cambridge: Cambridge University Press, 1990, 230-249; Marcus Willaschek, Praktische Vernunft: Handlungstheorie und Moralbegründung bei Kant. Stuttgart/ Weimar: J. B. Metzler, 1992, 169-193.

${ }^{4}$ Johann G. Fichte, "Zweite Einleitung in die Wissenschaftslehre." In Johann G. Fichtes sämmtliche Werk. Ed. von J. H. Fichte, Berlin: Verlag von Veit und Comp., 1845: 472.

${ }^{5}$ For example, cf. Kant, 2004: 307; 2003: 31.

6 As to the detailed comparative study on the practical philosophy of Husserl and Kant, cf. Thomas Cobet, Husserl, Kant und die praktische Philosophie. Analysen zu Moralität und Freiheit. Würzburg: Könighausen \& Neumann, 2003.

7 As to the relationship in ethics between Husserl and Brentano, cf. Ullrich Melle, " $\mathrm{Zu}$ Brentanos und Husserls Ethikansatz. Die Analogie zwischen den Vernunftarten.” Brentano-Studien 1 (1988): 109-120.

${ }^{8}$ Hua XXXVII, p. 220

${ }^{9}$ It should be pointed out that Husserl here used the pair of conceptions "formmaterial" in Kant's sense. Thus, one should not confuse Husserl's own concep- 
tions "form-material" with it, such as "formal praxeology-material praxeology" and "formal ontology-material ontology," etc. Husserl clearly emphasized that, "in this respect, we must clearly separate our way from Kant's doctrines" (Hua XXVIII, 2004: 139).

10 In this connection, I cannot agree with Henning Peucker. On the one hand, I think that Husserl's criticism of formalism (i.e. the universal emptiness) in Kant's ethics should not be confused with his criticism of Kant's "unreasonable" formalness without content. The latter means Kant missed the material feeling on the level of the grounds of prescription of the will and the value grasped in feeling. On the other hand, Husserl's "formal" praxeology should not be regarded simply as the "formalism" of ethics (cf. Henning Peucker, "Husserl's Critique of Kant's ethics." Journal of the History of Philosophy 45.2 (2007): 310, 313, 316ff.). In fact, Husserl also later criticized Brentano and his "formal categorical imperative." Limited to the length of the text, we will develop this point elsewhere.

11 See, Scheler, 1980: 83/65, footnote 19: "It is this prejudice that led Kant to the monstrous opinion that love and hate are 'sensible feeling-states'."

${ }^{12}$ It is necessary to distinguish several concepts used by Scheler here. Emotion (Emotion) is the broadest concept, which can include feeling (Fueblen), feelingstate (Gefüblsqustende) or feeling-content, preference (Vorziehen), rejection (Nachsetzen), affection (Affekt), love and hate, and such as empathy, pain, regret, shame, resentment, respect, humbleness, etc. In this sense, we can talk about Scheler's phenomenology of emotional life. In other words, the emotional a priori is used in this broadest sense as we talk about it in contrast with Kant's rational a priori. Sometimes Scheler directly said "a priori feeling." It is more against the school of English moral feeling and, of course, it can be said it's against Kant's moral feeling ethics in his second stage. Nevertheless, the difference in meaning expressed by "emotional a priori" or "feeling a priori" is clear, so we will no longer distinguish specifically between these two expressions in this paper.

13 We will discuss such essential differences in quality and depth in the field of feeling in the last section.

14 In the field of emotion/feeling, Scheler always used the expression of "grammar" too. For example, cf. Scheler, 1973: 22, 92, 112.

15 For deeper research on Husserl's ethics as rational theory and as area ontology, cf. Hans Rainer Sepp, Praxis und Theoria. Husserls transzendentalphilosophische Rekonstruktion des Lebens. Freiburg/Muenchen: Alber, 1997. 130-154.

16 Of course, the interconnections between "value-cognition" and "moral cognition" are presupposed here. We will discuss it elsewhere.

$17 \mathrm{~W}$. Henckmann once reminded us that one should not confuse the theory of value with ethics itself if one wants to correctly and systematically grasp the basic intention of Scheler's philosophy. Cf. Henckmann, 1998: 102.

18 For the detailed study on the relation of Husserl's theoretical philosophy to his ethics, see also Hans Rainer Sepp, Praxis und Theoria. Husserls transzendentalphilosophische Rekonstruktion des Lebens. Freiburg/Muenchen: Alber, 1997.

${ }^{19}$ Cf. Wei Zhang, "The foundation of phenomenological ethics: Intentional feelings." Frontiers of Philosopby in China. 4.1 (2009): 130-42. 
${ }^{20}$ A. Stüttgen discussed Husserl and Scheler' exploration on intentionality and founding relations in his doctoral dissertation. Limited to the objective conditions of study, however, he only dealt with the texts of Husserl's logical investigation and Idee I and Scheler's formalism, ethics and epistemology (X), and so on, but overlooked their other relevant manuscripts. So he was unable to develop the questions in his discussion in a detailed manner. Cf. Albert Stüttgen, Der Gegenstandscharakter der Werte bei Scheler im Hinblick auf Husserl. Bonn: Universitaet Bonn, Diss, 1957.

${ }^{21}$ Many thanks to Prof. Eugene Kelly (New York) and M. A. Wang Honghe (Köln) for modifying the English version of this essay. 